\title{
Changes of ecological wisdom of Sundanese People on conservation of wild animals: A case study in Upper Cisokan Watershed, West Java, Indonesia
}

\author{
SIDIK PERMANA ${ }^{1}$, JOHAN ISKANDAR ${ }^{1,2,3}$, PARIKESIT ${ }^{1,2,3}$, TEGUH HUSODO ${ }^{1,2,3}$, \\ ERRI N. MEGANTARA ${ }^{1,2,3}$, RUHYAT PARTASASMITA ${ }^{3, \vee}$ \\ ${ }^{1}$ Institute of Ecology (PPSDAL), Universitas Padjadjaran. Jl. Sekeloa Selatan I, Bandung 40134, West Java, Indonesia \\ ${ }^{2}$ Postgraduate of Environmental Science (PSMIL \& DIL), Universitas Padjadjaran. Jl. Sekeloa Selatan I, Bandung 40134, West Java, Indonesia \\ ${ }^{3}$ Department of Biology, Faculty of Mathematics and Natural Sciences, University of Padjadjaran. Jl. Raya Bandung - Sumedang Km 21, Jatinangor, \\ Sumedang 45363, West Java, Indonesia. Tel. +62 - 22 - 7796412 ext. 104. Fax. +62 - 22 - 7794545."email: rp2010rikkyo@ gmail.com; \\ ruhyat.partasasmita@unpad.ac.id
}

Manuscript received: 26 December 2018. Revision accepted: 11 April 2019.

\begin{abstract}
Permana S, Iskandar J, Parikesit, Husodo T, Megantara EN, Partasasmita R. 2019. Changes of ecological wisdom of Sundanese People on conservation of wild animals: A case study in Upper Cisokan Watershed, West Java, Indonesia. Biodiversitas 20: 1284-1293. In the past Sundanese rural people had a very close relationship with the environment. They utilize the natural resources based on traditional ecological knowledge (TEK) and is strongly influenced by their perception of nature. This article elucidates the mythology of Sundanese rural people on wild animals and the changes of rural people perceptions and their behavior to wild animals in the rural ecosystem based on a case study in Bojong Salam and Sukaresmi villages, Rongga district, West Bandung, the upper Cisokan watershed, West Java. Method used in this study was qualitative, while some techniques, including observation, participant observation, and semi-structured interview were applied. The result of study showed that in the past Sundanese the rural people of Upper Cisokan watershed, West Bandung, West Java owned myths on some wild animals that is inherited from their ancestor through oral and using mother language. The influence of these myths on wild animals caused the rural people had prohibited to kill these animals, and important role for traditional conservation. Nowadays, however, some myths on wild animals of rural people have not eroded or not recognized by young generations. Consequently, some taboos in hunting and catching animal based on myths on wild animals have tended not been applied to conserve wild animals traditionally. Therefore, to develop appropriate nature conservation, the biophysical, the socio-economic and cultural aspects must be holistically considered.
\end{abstract}

Keywords: Animal mythology, ecological wisdom, rural people, Sundanese, Upper Cisokan watershed

\section{INTRODUCTION}

Sundanese rural people residing in West Java have a strong relationship with their environment and its components such as wild animals. They perceive natural resources and environment not only for their economic values, but also as a sacred power that can influence their life. Based on their belief, therefore, they have respected their environment components, including wild animals (Toledo 1992; Iskandar 2014, 2017).

The respect of Sundanese people on environment components has built the local knowledge or traditional ecological knowledge (TEK), and generated wish behavior to their environment or ecological wisdom. Berkes (2008) defined TEK as 'a cumulative body of knowledge, practice, and belief, evolving by adaptive processes and handed down through generations by cultural transmission, about the relationship of living beings (including humans) with one another and with their environment'. The respect of rural Sundanese people on environment components can also be expressed as ecological wisdom to interact and treat wild animals that is strongly embedded by mythos and their belief. Both local knowledge and ecological wisdom on wild animals have been traditionally passed through generations by using oral of mother language and strongly based on culture (Alves and Souto 2015; Iskandar 2018; Permana et al. 2018).

Since rapid population increase, intensive economic penetration to rural area, technology and communication development, and ecosystem changes, the perception, and behavior of the rural Sundanese people toward wild animals had dramatically changed (Maffi 1999; Iskandar and Iskandar 2011; Partasasmita et al. 2016a). An example of the effect of an intensive penetration of market economy to West Javanese rural areas was that people started to hunt wild animals to fulfill their daily needs and lifestyle. Introduction of new agricultural practices such as applications of inorganic fertilizers and synthetic pesticides had seriously caused pollution on water bodies, including rivers and fish ponds that were the habitats of fishes and various water organisms. In addition, forest clearing, intensification of agriculture, and infrastructural development projects had affected and destroyed the habitat of wild animals. As a result, some negative human activities on environment have caused decrease or even extinction of some wild animals in rural areas of West Java (Iskandar 2014; Iskandar 2015). 
Although some wild animal habitats had been destroyed or disappeared in many rural areas of West Java, some wild animal species of upper Cisokan watershed have still been predominantly found. It has been caused by several factors, including existence of ecological wisdom in the forms of local myths and beliefs. For example, some rural of Ciskokan in the past prohibited the killing of wild animals due to their myths and beliefs in spirits of their ancestors and animals (Wessing 1978; Permana 2015; Iskandar 2018). The myths and beliefs of the local people have actually been studied by some anthropologists as they played an important role in conservation of nature, including biodiversity, rare species, ecological processes, and management of natural resources (Horowitz 1998; Berkes et al. 2000; Emieaboe et al. 2014).

Studies on local wisdoms of rural people on conservation of natural resources based on TEK and embedded by cosmos or belief have been undertaken by some scholars, including studies on wild animals and hunting animals, birds, fish, and forest (Nikijuluw 1998; Pawarti et al. 2012; Endri et al. 2015; Iskandar et al. 2016; Partasasmita et al. 2016a; Alandra et al. 2018)

This article elucidates the mythology of Sundanese rural people on wild animals, including boar pig, pangolin, leopard, javan gibbon and monkey, and paseban fish; and the changes of rural people perceptions and their behavior toward wild animals in rural ecosystem based on a case study in Bojong Salam and Sukaresmi Village, Rongga district, West Bandung, the upper Cisokan watershed, West Java, Indonesia.

\section{MATERIALS AND METHODS}

\section{Research location}

This research was conducted in the Sundanese local communities residing in two villages in the upper Cisokan Watershed, namely Bojong Salam and Sukaresmi Villages, Rongga Sub-district, West Bandung District, West Java Province, Indonesia (Figure 1).

Bojong Salam and Sukaresmi Villages are located in Rongga Sub-district, West Bandung District, West Java Province, Indonesia. Rongga Sub-district is situated in the southwest of Bandung, the capital of West Java. The distance from Bandung City to Rongga Sub-district is approximately $72 \mathrm{~km}$ and can be reached by vehicles passing asphalt road for about 4 hours.

Bojong Salam Village is located at the west of subdistrict office of Rongga. The distance from the office to the village is approximately $7 \mathrm{~km}$. Bojong Salam can be reached from Rongga by village transportations, namely motor bike (ojek) and the village public small car (angkutan pedesaan) through asphalt road within 20-30 minutes. Bojong Salam has a total area of approximately $2,981.8$ ha. The population density of this village was about 180 persons $/ \mathrm{km}^{2}$ in 2016. It has some land use types, namely settlement and homegarden, river, irrigated rice field, mixed-garden, swidden farming, tea plantation, and secondary forest.

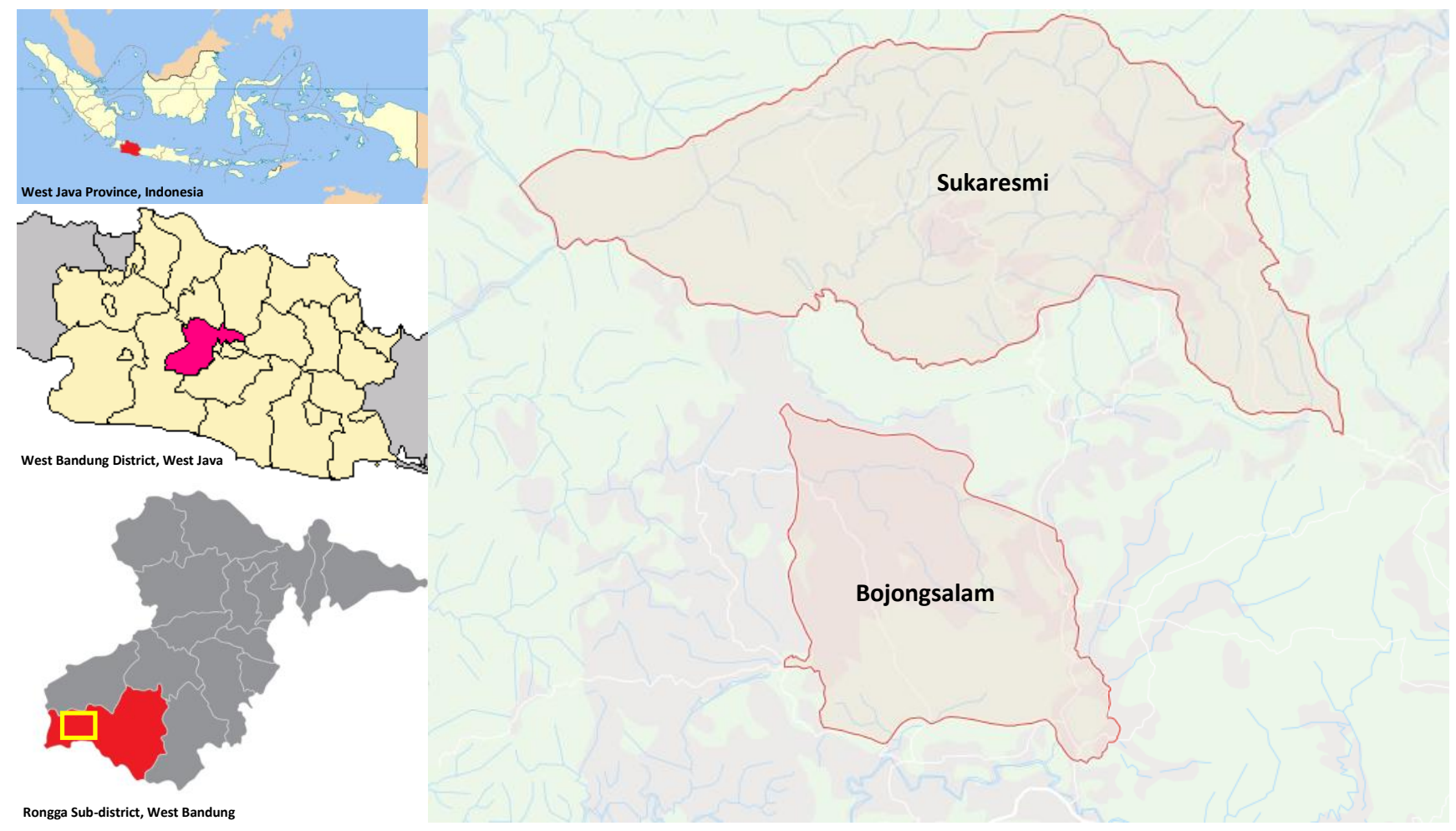

Figure 1. Map of Bojong Salam and Sukaresmi Villages, Rongga Sub-district, West Bandung District, West Java Province, Indonesia 
Sukaresmi Village is located in the south of Rongga Sub-district. It has a total area of about $1,660.74$ ha. Population density of this village was 494 person $/ \mathrm{km}^{2}$ in 2016. The distance from Sukaresmi to Rongga District office is about $8.5 \mathrm{~km}$, while the distance from this village to provincial capital is about $80 \mathrm{~km}$. The village can be reached by public transportations, namely ojek or public car, for approximately 21 minutes from Rongga and 4 hours from Bandung. Some land use types, namely settlement, and homegarden, mixed-garden, swidden farming, river, wet rice field, and secondary forest, were found in Sukaresmi Village.

\section{Method and technique}

The method used in this study was qualitative, and some techniques, including observation, participating observation, and semi-structured interviews, were applied to collect primary data (Cunningham 2001; Albuquerque et al. 2002 Iskandar 2018). Observation was conducted to examine the condition of wild animals in rural ecosystems and their habitats. Participating observation was undertaken by actively participating in the activities of respondents, namely hunting animals by using various traditional traps. The hunted wild animals included red jungle fowl (Gallus gallus bankiva), porcupine (Hystrix javanica), java mouse-deer (Tragulus javanicus), pangolin (Manis javanica), wild boar (Sus scrofa) and various birds. We participated in hunting preparation and setting-up the traditional traps, jiret and pitangkreb. Jiret is traditional trap to catch ayam hutan (Gallus gallus varius) and other birds, while pitangkreb is commonly used to catch porcupine and pangolin. Both jiret and pitangkreb were set under canopy of various trees at river banks, swidden farming, and mixed-garden. The jiret and pitangkreb were inspected twice daily, in the morning and the afternoon.

Semi-structured interviews or deep interviews were conducted using respondents with competent information, that were purposely selected. The informants consisted of old farmers, animal hunters (hunters of porcupine, pangolin, wild boar and birds), and the informal and formal leaders. The interviews were conducted casually in the house of informants during their leisure time. The competent informants were local people who possessed a lot of knowledge on the local mythology of wild animals and wild animal species, as well as experiences in hunting them (Warner and Bernard 1994; Permana 2015; Iskandar 2018). They were happy to share their experiences and knowledge on wild animal species and their mythology, beliefs, folklore, hunting tools and hunting techniques.

\section{Analysis of data}

The data were cross-checked, summarized, synthesized, and made into narrative descriptions (Newing et al. 2011; Iskandar 2018). Cross-checking was conducted to validate data obtained from observations, deep interviews, and participating observations. Unlike the quantitative analysis, the qualitative analysis was carried out directly in the field. Some activities, such as collecting information, sorting information into several groups, formatting information into a story, tables and pictures, and writing narrative descriptions, were made either in the field or in the office. The qualitative analysis consistently considered two perspectives, namely informant's perspective (emic view) and researcher's analysis (ethic view) (Iskandar 2018).

\section{RESULTS AND DISCUSSION}

\section{Wild animals in the study area}

Bojong Salam and Sukaresmi Villages were very steep hill area. Their land use type consisted of settlement and home garden, wet-rice field, river, mixed-garden (talun or kebun tatangkalan), and forest (Figure 2). The wet-rice field was located in the valley by the Cisokan River. Various plants were planted along the river and formed as a riverine forest. Parts of the hills were found as mosaics in form of mixed gardens, swidden farming (huma), and Perhutani production forests. The mixed-garden contained perennial and annual crops, including palm sugar (Arenga pinnata), bamboo (Giagantochloa apus), jackfruit (Artocarpus heterophyla), albazia (Paraserianthes falcataria), and banana (Musa x paradisiaca).

Forests in both Bojong Salam and Sukahaji consisted of two type of forests, namely planted and natural forests. The planted forest was pine (Pinus merkusii) production forest that was managed by Perhutani. The natural forest consisted of riverine forest along Cisokan River and the remnant natural forest of Cigowek. Some plants, including Ficus sp., Piper aduncum, Artocarpus elasticus, Macaranga tanarius, and Spatodea campanulata, were predominantly found growing in the riverine forest. Some distinctive forest trees, namely Dysoxylum parasiticum, Dipterocarpus hasseltii, Ficus retusa, Artacarpus elasticus, Ficus variegata, and Ficus sp., were dominantly found in the remnant forest of Cigowek.

Although the rural ecosystem of upper Cisokan watershed, West Bandung, West Java, has been extensively used for agroecosystem, various fauna had been found in the area. As many as 213 species of fauna comprising 36 species of mammals, 114 species of birds, 48 species of herpetofaunas, and 15 species of fishes were documented from the upper Cisokan, where a dam for the electric state company PLN was built (PLN-LLPM Unpad 2017). Ten families of the animals were mentioned in the local myths of Bojong Salam and Sukaresmi. Four out of the 10 species were categorized as protected animals in Indonesia based on the Minister of Environment and Forestry of Republic of Indonesia No. P.92/Menlhk/Set.jen/Kum.1/2018, and seven species were listed on the International Union for Conservation of Nature and Nature Conservation Red List of threatened wild animal species (Table 1). 

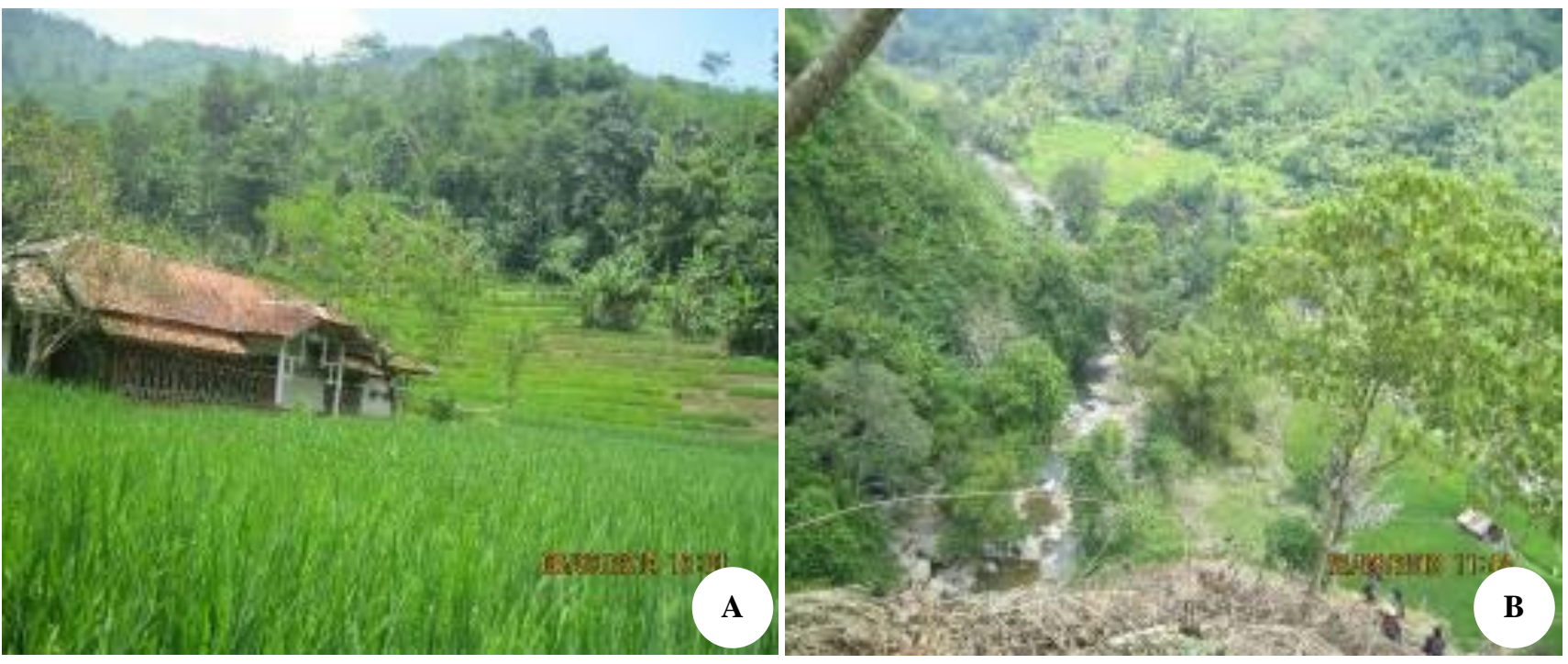

Figure 2.A. The home garden, wet-rice field, and mixed-garden are predominantly found in Bojong Salam and Sukaresmi, upper Cisokan watershed, West Java, Indonesia. B. Riverine forest is found along Cisokan River, West Java, Indonesia, and swidden farming and mixed-garden are found in the upper part area

Table 1. Various animals in the local myths and beliefs of rural people of Bojong Salam and Sukaresmi, Cisokan watershed, West Java, Indonesia

\begin{tabular}{|c|c|c|c|c|}
\hline Wild animal species & Vernacular name & Family & Common name & Conservation status \\
\hline Aonyx cerea & Sero, berang-berang & Mustelidae & $\begin{array}{l}\text { Oriental small- } \\
\text { clawed otter }\end{array}$ & Not protected, IUCN Red List of IUCN \\
\hline Hylobates moloch & Owa & Hylobatidae & $\begin{array}{l}\text { The slivery } \\
\text { gibbon }\end{array}$ & Protected in Indonesia*), IUCN Red List $* *$ ) \\
\hline Leobarbus douronensis & $\begin{array}{l}\text { Ikan kancra, kancra } \\
\text { bodas }\end{array}$ & Cyprinidae & God's fish & Not protected \\
\hline Macaca pascicularis & Monyet, kera & Cercopithecidae & $\begin{array}{l}\text { Crab-eating } \\
\text { macaque }\end{array}$ & Not protected \\
\hline Manis javanica & Peusing, trenggiling & Manidae & Pangolin & Protected in Indonesia*), IUCN Red List**) \\
\hline Nycticebus javanicus & Muka, kukang & Lorisidae & Javan slow loris & Protected in Indonesia*), IUCN Red List **) \\
\hline $\begin{array}{l}\text { Paradoxurus } \\
\text { hermaproditus }\end{array}$ & $\begin{array}{l}\text { Careuh, careuh bulan, } \\
\text { musang }\end{array}$ & Viverridae & $\begin{array}{l}\text { Common palm } \\
\text { civet }\end{array}$ & Not protected in Indonesia, IUCN Red List $* *$ ) \\
\hline Panthera pardus & Macan tutul & Felidae & Leopard & Protected in Indonesia*), IUCN Red List **) \\
\hline Presbytis aygula & Surili & Cercopithicidae & Grizzled langur & Protected in Indonesia*), IUCN Red List **) \\
\hline Sus scrofa & $\begin{array}{l}\text { Bagong, bedul, babi } \\
\text { hutan }\end{array}$ & Suidae & Wild pig & Not protected \\
\hline
\end{tabular}

Note: *) Protected Animals in Indonesia based on the Minister of Environment and Forestry of Republic of Indonesia, No. P.92/Menlhk/Set.jen/Kum.1/2018. **) IUCN Red list, http: //www.iucnredlist.org/about

\section{Mythology of rural people}

The Sundanese rural people, particularly in the past, believed in spirits of the dead, the place (jurig), and dewa dewi (Indian derived gods and goddess) (Wessing 1978). They also believed in various shapeshifting of animals, as described by some scholars such as Wessing $(1978,1993$, 1995), Rye (2000), and Iskandar (2018). Regarding the belief in animal shapeshifting, Wessing (1978) expressed it as 'apart from human sacrifice there are other ways in which payment to the spirit can be made'. These included agreement to turn into an animal after death, or marriage to one spirit that took either a human or animal form. Depending on the animal involved, the name for the agreement varied, including ngetek (agreeing to become a monkey), nyegik (agreeing to become a wild boar), ngipri (agreeing to become a female snake), and nyupang (agreeing to become a female crocodile).

Our study revealed that rural people of Bojong Salam and Sukaresmi Villages believed in myths of wild animals, such as wild boar (Sus scrofa), pangolin (Manis javanica), leopard (Panthera pardus), javan gibbon (Hylobates moloch), Crab-eating macaque (Macaca fascicularis), slow loris (Nycticebus coucang), and kancra fish (Leobarbus douronensis).

\section{Myth of wild boar}

On the basis of local knowledge (TEK) of Sundanese people in Cisokan area, they recognized two kinds of boar: real animal of wild boar and mythological boar. The real animal boar (Sus scrofa) was locally known as bagong, 
bedul, or babi hutan. In addition to real wild boar, the Sundanese people recognized a myth of pig that was called as 'magical pig' (bagong sakti). According to the myth, bagong sakti had white neck, and was immune to any weapons or any hunters. The myth of 'magical pig' had been popular, particularly among the old generation of Cisokan villages.

Based on information from respondents, the magical wild boar was found in some areas of Cisokan watershed, including forest of Cigowek, Boregah, Curug Kunti, Cimarel, Ciawitali and Muara tilu. Based on the local myth, during the Dutch colonial in the past there was an old man in Babakan Bandung, Sukaresmi Village, who mastered a magic power called as 'ilmu batara karang'. After he died, his spirit possessed the body of a boar (Wessing 1978). One of informant, who resided in Babakan Bandung, exclaimed that he saw with a magical pig in his homegarden. He said that the magical pig had a white neck and was perceived as manifestation of magical wild boar. Then, he shot the magical wild boar using a traditional gun (bedil cuplis). The next day he checked the place where he shot the boar, but did not find the dead boar but a flat shotgun bullet instead. He believed that the bullet actually hit the body of magical boar.

Since people have believed in the myth of magical wild boar, the wild boar can cause serious damage on various crops in the garden, mixed-garden, and swidden farming. The exterminating or killing the magical pig was done using certain incantations by old shamans (Rao 2002; Iskandar 2018). Unlike the magical wild boar, common wild boar or real animal wild boar have been perceived do not have super natural power and is allowed to be hunted by the rural people. Based on village tradition, it has been very popular traditional wild boar hunting twice a week using the help of a dog that is locally called as moro bagong. The tradition of hunting animals has been traditionally carried out not only in Cisokan watershed but also in other villages of West Java or other villages of outer Indonesia (Puri 2005; Iskandar 2014).

\section{Myth of pangolin}

Although most people of Cisokan watershed knew the pangolin, or peusing (Sundanese) or trenggiling (Manis javanica), however, only the old generation knew about the myth of pangolin. According to informants, who were old people of Cisokan, the pangolin had been perceived initially as a kind of fish, named as ikan kancra that transformed to be pangolin. Based on the myth, the ikan kancra was guarded by Nabi Kidir who guarded the water and ocean, and Nabi Sulaiman guarded animals on land. When Nabi Kidir wanted to spread ikan kancra to a river, several individual fish of kancra fell down on to the land and changed to pangolins. As a result, the pangolin had a lot of scales similar to ikan kancra. In addition, the rural people of Cisokan believed that during the night pangolins went back to their nests. But if the eastern constellation appeared can be used as indicator night time changes to be the day, and pangolin will stop anywhere.

Based on this myth, rural people of Cisokan believed that in the wet season, the pangolin usually goes up to a high place or forest, while in the dry season pangolin goes down to the river and changes shape to be ikan kancra. The old people of upper Cisokan also believed that it was taboo kill this animal. Based on informants, there was an old man from their ancestors who forbade his descendants to kill pangolins because he had been helped by a pangolin when he fell into a hole in the ground. Therefore, in the past the rural people of Cisokan were prohibited from killing pangolin in their village area.

\section{Myth of leopard}

Rural people of Cisokan watershed knew three kinds of tigers in the area, namely macan loreng or lodaya (Panthera tigris sondaica), macan tutul or macan totol (Panthera pardus melas), and macan kumbang (Panthera pardus) is a black panther of sub-species of panther. Panthera tigris sondaica was considered to be extinct in West Java region before 1980s (Whitten et al. 1999; Iskandar 2014), but Panthera pardus was still found in the Cisokan upper watershed (Shanida et al. 2018)

Like most rural Sundanese people, rural people of Bojong Salam and Sukaresmi Villages have myths on tigers. They believe that the King of Pajajaran (Western Java), Prabu Siliwangi, transformed into a tiger after he died. They also perceived that men who have supernatural are considered as descendant of Prabu Siliwangi who disappeared and became spirit of tiger (Wessing 1995). Since they had believed that their ancestors were the spirit of Prabu Siliwangi, before traditional ceremony of the wedding and the circumcision, they made offering to ancestors in of various materials, including raw meat, traditional cake made from sticky rice (opak), eggs, etc. After reciting a prayer $\left(d o^{\prime} a\right)$ to their ancestors, various offerings were left in the hill (tegalan). In addition, based on myth story on tiger or leopard spirit, in the past the old man who owned a tiger spirit, he traveled for long distance and crossed a river only for short time. If the old man who has ancestral spirit need to assist, he could as the name of his ancestor (karuhun) for obtaining assistance. By closing his eyes and provided a prayer, and the ancestor in the form of tiger would appear suddenly to help him. In the past, if someone who owned the ancestors spirit, if he got any problems, such as a threat of danger by criminals, then he would call the names of the ancestors by stepping on the ground 3 times, then the spirits of the ancestors would come into the body in the form of pamacan and saved him from the threats.

Another myth said that when someone who owned spirit of leopard in Babakan Badung Hamlet of Bojong Salam Village, was lighting a bonfire at night in his mixed gardens, he was accompanied by a leopard on his side. In short, unlike boar pig, leopard particularly in the past was feared or even respected but not hatted. As a result, the rural people had been in harmony with the leopard, and this animal were rarely killed by rural people.

\section{Myth of owa and monkey}

The field survey found that owa/the javan gibbon (Hylobates moloch) and monkey/Crab-eating macaque (Macaca fascicularis) were predominantly found in rural 
ecosystem of the upper Cisokan area. Rural Sundanese people of upper Cisokan area had a myth related to owa and monkey, that was leopard took an offering or victim (wadal) to owa and monkey. One monkey was taken as an offering to the leopard every year. This was known as tunji, which stands for sataun hiji or one individual for each year. There was also another offering called lanji, which stands for sabulan hiji or one month for one individual, for one owa becoming an offering to the leopard every month. The perception of rural people can be interpreted as ethnozoological point of view, the leopard myth took the offering or victim to actually portray and legitimize the relationship between predators and preys, that owa and monkey were the main preys of leopards (Raharyono and Puripurno 2001).

Owas was known by rural people as a good animal (bageur), because it never did anything that harmed the rural people. The rural people believed that owa was guarded by the ancestral spirits named Mbah Layung who lived in the Cigembong area, Bojongsalam Village. This story came through the dreams (ilapat) of one of the informal leaders in Bojongsalam Village, in which he was visited by Mbah Layung who gave him a message not to disturb and hunt owa. He also committed to the mandate of the ancestor, if one day he found owa hunters, he would arrest, chased and scolded them

The local people also believed in myths on shapeshifting of monyet, owa, luwak/careuh, and surili into a macan tutul/leopard. A group of monkeys gathered in the trees and pushed each other with their noisy voices until one of them fell down. The fallen monkey would be eaten by a leopard, or would be separated from the group. If survived, then the monkey climbed to a tree and dwelled in the ferns of the sarang burung/kadaka (Asplenium nidus), and eventually would turn into a leopard after some time. The monkey stayed in silence for a long time which was known as meditating or tapa, and as long as the four species are ascetic, the rural people did not dare to interfere.

In the past, leopards never visited people's settlement to kill domesticated animals, because the natural forest still housed lots of preys.

\section{Myth of kukang}

Like common tradition of Sundanese people, rural of Bojong Salam and Sukaresmi have myth story on kukang/javan slow loris (Nycticebus javanicus). Based on the local people perception, they believed that the Javan slow loris face was frightening (sangar), so they would not disturb the animal because that would cause bad luck (Nijman and Nekaris 2014). If a kukang was killed, the blood dripping on the ground would cause disaster to the rural people of one hamlet. Therefore, it was prohibited (pamali) to disturb, capture, or kill a kukang. The Javan slow loris could also be used to harm other people, using its fur, bones, and blood. According to the informant, fur of kukang was traditionally used to making bad luck worldly affairs, which the feathers were dropped on land or houses of other people. A kukang bone was buried in the homegarden of a person who was meant to be harmed/killed. Droplets of kukang's blood were spread on the homegarden or village to cause disaster or danger.

\section{Myth of berang-berang}

People believed that berang-berang/sero (Aonyx cinerea) usulally live in a group. They are led by a group head who has a talisman called mustika. If the head of the group takes out feces, mustika usually comes out of the feces. So, mustika mixed with feces is contested because who gets the gift will become the head of the group. Therefore, every sero feces is usually found in the form of scattered like a mess (Iskandar 2015). Mustika of sero had the size of a red bean and red color. Based on the myth, the mustika can be used to invite fish in the water bodies, including river and fish pond. The rural people also believed that when the sero group consisting of ten individuals will find foods, including fish and crabs accompanied by dead of spirit that is called as kunti (cf. Wessing 1978). Since the sero group that were catching fish and crab have usually produced a loud sound similar to that of kunti, many rural people are generally very scared of kunti.

Rural people had knowledge of the myth of sero and its distinctive behavior. It is a nocturnal animal, therefore people recognized this animal mainly based on its distinctive feces that was found in river banks or other water bodies, including fish pond of the rural ecosystems.

\section{Myth of paseban fish}

In the past, rural people of the Upper Cisokan, West Java utilized river fishes based on the traditional ecological knowledge and believe or cosmos. For instance, based on their tradition, they believed that it has been known certain kind of sacred fish called as paseban that lives in the river and usually annually moved to upstream particularly in the beginning of rainy season

The rural people of Bojong Salam and Sukaresmi believed that a group of fish, called as ikan leuwi pasebaan (leuwi meaning the deep part of the river), annually moved upstream in the upper area of Curug Walet. The paseban, meaning a place to give a tribute, was considered as a place of offering a tribute (upeti). When the fish migrated to the paseban upstream, it was then prohibited to catch the fish. If anyone caught any fish in the paseban, he/she would get problems, or even die. The rural people also believed that the fish was assisted by magical crab (keuyeup ajaib) to magically migrate upstream. This myth seems to refer to species of fish that migrates upstream to lay eggs and swims back downstream afterward (PLN-LPPM Unpad 2017). People were allowed to catch fish that was moving downstream.

The prohibition of catching fish during paseban time in the upper Cisokan watershed case is similar to that in Kampuang Surau, West Sumatra (Pawarti et al. 2012). According to their tradition, the rural people of the Surau Hamlet should not interfere, arrest, harm fish, and say arrogantly on the river area which was designated as lubuk prohibition because the area was considered as sacred. People were allowed to catch fish only if there was an agreement regarding the time of catching fish in the 
consensus that was decided by the adat regulation. Anyone violated it would be subject to trial and adat sanction. Another study by Nikijuluw (1998) on communities in Maluku recorded that the local people were prohibited to catch fish in the sea determined by adat leaders as sasi areas at certain times. They were allowed to catch fish when the prohibition had been opened (buka sasi) by the sasi leader who also served as the village chief.

The tradition of Cisokan villagers to forbid fishing on migratory fish or paseban time apparently played an important role in the conservation of the fish. This allowed the fish to regenerate normally. The species of this migrating fish was kancra (Leobarbus douronensis).

\section{Changes in ecological wisdom}

In the past, the Sundanese rural people, including rural people of Bojongsalam and Sukaresmi Villages, believed in spirits of the ancestors. They believed that after the death, their relation with the deceased was not broken off. The ancestors had a very powerful force in Sundanese life. Ancestor spirits may appear in the form of a tiger, that was a symbol of power and noble lineage to the old Pajajaran kingdom (Wessing 1978). Therefore, the tiger was respected by rural people, and consequently, the tiger or leopard was not allowed to be killed. On the contrary, Javan slow loris (Nycticebus javanicus) had a mystical value in rural Sundanese society, in which they believed that the animal was associated with bad luck. As a result, the animal had been killed (Nijman and Nekaris 2014; Partasasmita et al. 2016a; Partasasmita et al. 2016b).

Today, both ecosystem and social system have dramatically changed, and various mythical values in rural Sundanese community of upper Cisokan have disappeared. Some prohibitions to kill mythical animals, such as pangolin/trenggiling/peusing (Manis javanica), the silvery gibbon/owa (Hylobates moloch), grizzled langur/surili (Presbitis aygula), palm civet/careuh (Paradoxurus hermaphroditus), and leopard/macan tutul (Panthera pardus), were not applied any more.

Nowadays, people have commonly hunted and killed pangolin for the meat is used for either household consumption or for selling in the market. The pangolin hunters usually hunted pangolin by digging holes and smoking it in the pangolin nest in a ground hole or cave. Consequently, the pangolin came out of the hole and was caught by hit of wood or a bamboo stick. In general the hunters had known habitat and nest of pangolin. For example, it was recognized as habitat of pangolin in Cibungbulan waterfall of the Upper Cisokan watershed. The hunted pangolins were usually used both for home consumption as source of animal protein and sold to village midle men. One individual of pangolin can be sold approximately between Rp 250,000 and Rp 300,000 in 2017.

Other primates, including owa and surili have been also commonly hunted-by rural people. According to informants, both owa and surili often visited the gardens and swidden farming to look for foods, such as banana (Musa x paradisiaca). Since owa and surili damaged various crops, the rural people hunt these animals while they were hunting wild boar. The wild boar hunting has been regularly carried out each week by both people of the upper Cisokan and outside of the Cisokan area using a spear and assisted by a dog (Figure 3.A). Not only wild boar, some other animals such as pangolin and porcupine were also hunted. Both animal were hunted in their hiding places, such as in stone caves in the hill area by smoking the cave to lure the animals out (Figure 3.B). The hunted animal was sold to people both in the village or urban area.

The people of upper Cisokan also caught birds for keeping them in the cage in the past rural. They looked for chicks that were still in the nests. Today some rural people of Bojong Salam and Sukaresmi trapped birds to be sold to middle-men in the village or bird markets instead of for keeping them in the cage as hobby. In addition to local people, many people from outside of the village came to upper Cisokan area for hunting birds by using some other means, such as using spear, trap (jiret and pitangkreb), and gum of rubber trees (Hevea braziliensis), jackfruit (Artocarpus heterophyllus), and teureup (Artocarpus elasticus) that was put in a bamboo stick or wooden branch (Figure 3.E-F).

Various bird species such as kutilang/cangkurildeung (Pycnonotus aurigaster), anis (Zoothera citrina), ciblek (Prinia familiaris), murai/manuk haur (Copsychus saularis), prinjak (Orthotomus rificeps), pleci (Zosterops palpebrosa), and tikukur (Streptopelia chinensis) were predominantly caught by local people. All caught birds were collected and put in cages that were hung in front of the hunter house (Figure 4.a) and then later to be sold in the urban bird markets of Cianjur and Bandung (Iskandar et al. 2016).

The intensive swidden farming and recent conversion of forest land to infrastructure facilities for the Electric State Company (PLN), and access roads, have caused habitat destructions or habitat loss of wild animals. Therefore, the home range of wild animals, particularly leopard (Panthera pardus), had been narrowed. In addition, preys of leopard had been dramatically decreased due to habitat loss and illegal hunting. As a result, the leopard started to prey on domesticated animals such as cattle, sheep, and dogs (Table 2 ). The rural people made more permanent sheep cages to prevent them from being preyed by the leopard (Figure 4.B).

Table 2. Some occurrences of leopard preyed on the domesticated animals of rural people of upper Cisokan Watershed, West Java

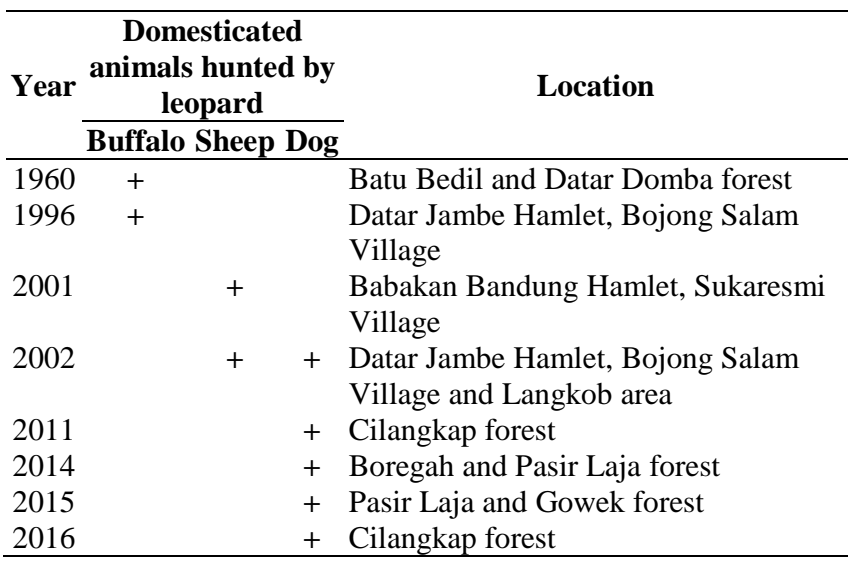




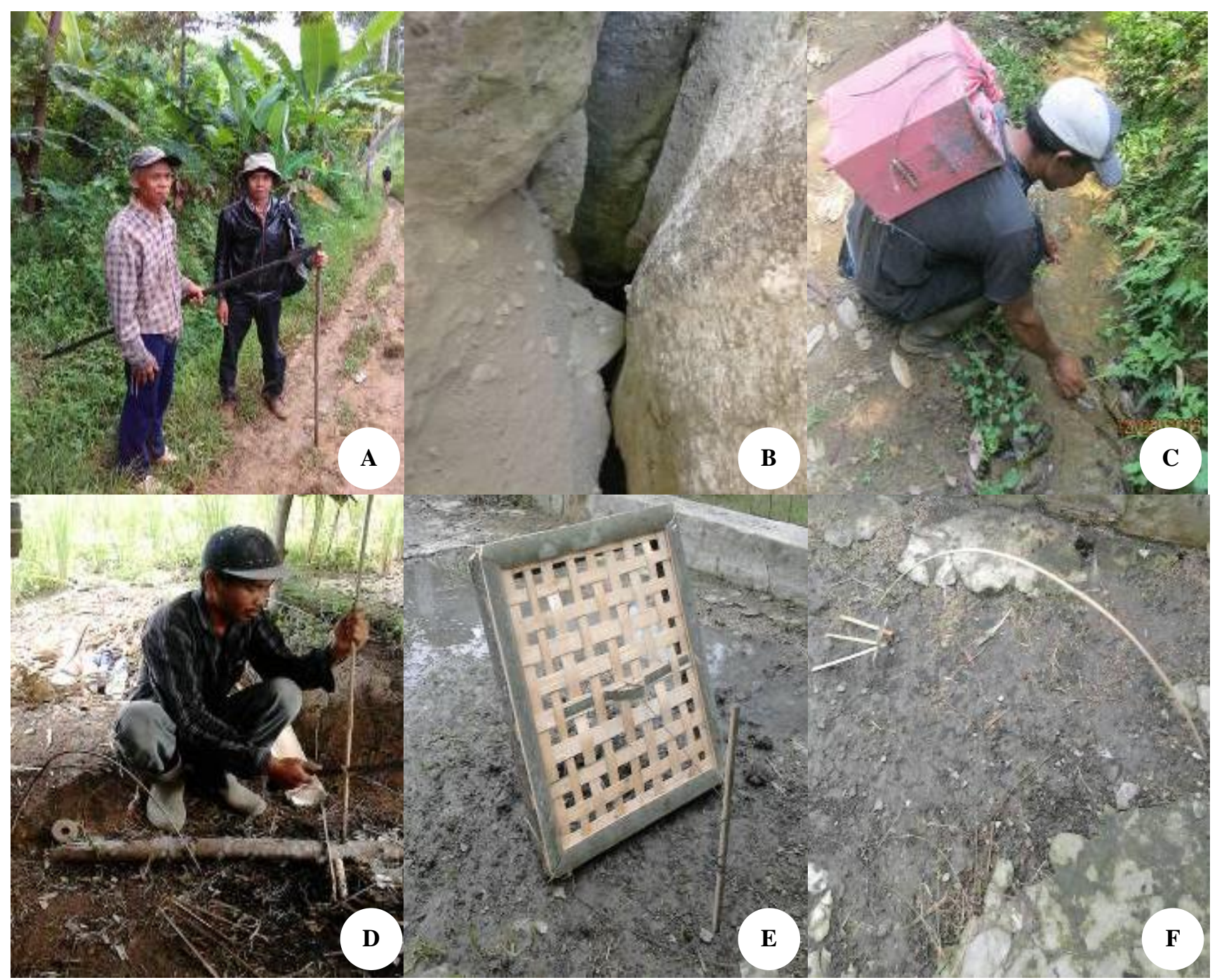

Figure 3. A. Wild boars (moro bagong) hunters holding a spear in the rural area of the upper Cisokan watershed, B. The animal hunters usually smoked the cave where the hunted porcupines rested or hid, C. A bird hunter was washing his hands in a ditch after installing a stick of bird on a tree branch, D. A man was installing a trap to catch birds in the swidden farming, E. A trap of birds (pitangkreb) that was commonly used by bird hunters to catch birds, F. A trap of birds (jiret) that was commonly used by bird hunters to catch birds

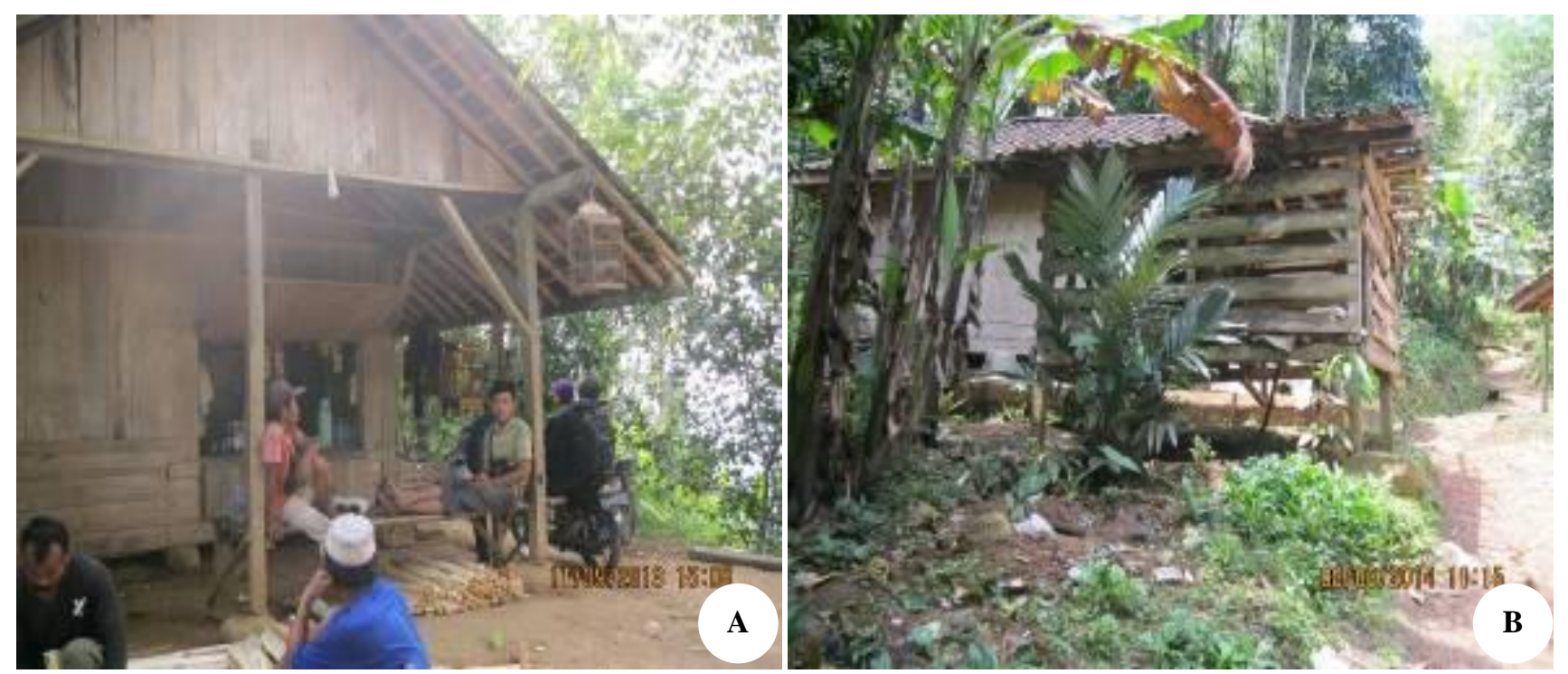

Figure 4.A. Caught birds were kept in cages and hung in front of houses for selling in the urban bird markets, B. The sheep cage was made permanently to avoid being killed by tigers entering the village 
The development of access roads to the PLN site project also disturbed leopard hiding place. The expansion of the swidden farming practices to steep hillside slopes as a result of economic pressure resulted in the decrease of the natural forests which were the habitat many wild animals. The local people own the swidden agricultural land (huma) in limiting size of average between 3 and 5 gawang (1 gawang $=400 \mathrm{~m} 2$ ). In addition, to have their private agricultural land, they usually obtained agricultural land based on sharecropping from the Perhutani. Since the swidden agricultural land and mixed garden (kebun campuran or talun) are located directly adjacent to the Perhutani forest area, some conflict between wild animals, including lutung, monkey, and surili often occurred. Because those animals usually come to the agricultural land, they eat various crops, including rice and other annual crops, could cause harm to farmers.

Another environmental change was the conversion of forest plantation into settlements. Before the settlement establishment in 2015, only one household resided in Babakan Bandung Hamlet of Sukaresmi Village, and the area was dominated by forest trees (hieum) that housed many wildlife, and grazing place for their livestock. Nowadays, there are 30 families in the hamlet, and another 15 families in Lembur Sawah Hamlet. Similar to Babakan Bandung Hamlet, Cangkuang Hamlet of Bojong Salam Village was predominantly by a forest/plantation area, and was occupied only by four households. This place was then converted to a new settlement in 2016 and resided by 18 families from Ciawitali Hamlet and 7 families from Pamipiran Hamlet. As a result, the total population Cangkuang Hamlet has become 29 households in the new settlement and their old settlements were converted to the PLN project site. Since the new settlements have increased, the habitat of wild animals decrease and some conflicts between farmers and wild animals could not be avoided. Some wild animals had become pests for their swidden farming and garden agroecosystem, such as monkey and wild boar. Conversely, people started to intensively hunted and killed the animals.

It can be concluded that the Sundanese rural people in the past had closed relationships with the environment. They used natural resources, including wild animals in the rural ecosystem based on traditional ecological knowledge (TEK) and embedded with their culture. Culturally the Sundanese rural people had various mythical stories related to wild animals in the rural ecosystem. The influence of these myths caused the rural people had carefully treated and had been taboo to kill the mythical wild animals. Therefore, the taboo system can be considered as ecological wisdom and has been an important role in conservation of wild animals in rural ecosystems. However, nowadays due to rapid population growth, rapid technological, communication, market economic development, and various ecosystem changes, the ecological wisdom had been eroded or lost. As a result, some wild animals that were never been killed due to taboo based on myths in the past, had been freely hunted or killed. Nowadays, however, due to rapidly increased of rural human population, highly developed technology and information, intensively the penetrated of the market economy into rural areas, and decrease of forest converted to agricultural land and development projects, including PLN project, the tradition conservation or local wisdom of rural people on wild animals based on traditional ecological knowledge and beliefs or cosmos, and myths have eroded or extinct. For example, nowadays, the rural people myth on slow loris have dramatically changed. Today Sundanese rural people's perception of slow lory is no longer a frightening animal, but it is perceived as an animal that can be traded and can provide economic benefits. Consequently, nowadays slow loris although has been protected by the Indonesian law, this animal is predominantly hunted and illegally traded. Therefore, to ensure the success of natural conservation, including the conservation of wildlife diversity, inattention to various biophysical or ecological aspects, it is also important to pay attention to various aspects of socio-economic and cultural systems of the rural people with its various changes. In another world, the traditional conservation of nature and wild animal species considered biophysical aspects only without regarding social aspects, therefore the purpose of conservation would not be achieved in many developing countries.

\section{ACKNOWLEDGEMENTS}

We are grateful to the village leaders and staff of Bojong Salam and Sukaresmi Villages, and Rongga Subdistrict, for providing permission to conduct research in villages in the upper Cisokan, West Bandung, West Java. We are also grateful to our respondents of the rural people of Bojong Salam and Sukaresmi for providing various information when we were conducting research in their village. This paper publication is supported by ALG (Academic Leadership Grant) of Prof. Johan Iskandar, with the main topic is titled as "Ethnobiology for the People Welfare to support the Sustainable Development". Therefore, authors would like to thank Rector of Padjadjaran University, Prof. Tri Hanggono has supported the publication. We would like to thank the Head of Department of Biology who have been supporting this publication.

\section{REFERENCES}

Alandra Y, Amelia FUD, Iskandar J. 2018. The traditional rimbo larangan system of forest management: sn ethnoecological case study in Nagari Paru, Sijungjung District, West Sumatra, Indonesia. Asian J Ethnobio 1 (2): 61-68.

Albuquerque UP, da Cunha LVFC, de Lucena RFP, Alves RRN. 2002 (eds). Methods and techniques in ethnobiology. Springer ScienceBusiness Media, New York.

Alves RRN, Souto MS. 2015. Ethnozoology: a brief introduction. Ethnobio Conserv 4 (1): 1-13 Doi: 10.15451/ec2015-1-4.1-1-13.

Berkes F, Colding J, Folke C. 2000. Rediscovery of traditional ecological knowledge as adaptive management. ecological applications. United State of America: Ecological Society of America.

Berkes F. 2008. Sacred ecology. Second edition. Routledge, New York. 
Cunningham AB. 2001. Applied ethnobotany: people, wild plant use and conservation. Earthscan Publications Ltd, London.

Emieaboe PA, Ahorsu EK, Gbogbo F. 2014. Myths, taboos and biodiversity conservation: the case of hunters in rural community in Ghana. Ecol, Environ Conserv 20 (3): 879-886.

Endri N, Iskandar J, Parikesit. 2015. Communal land forest management with zoning system and its effect on biodiversity of birds in Nagari Simanau, Solok Regency of West Sumatra. Proceeding National Conference and observer of birds Indonesia. Bogor Agriculture Institute, Bogor, 13-14 February 2015. [Indonesia].

Horowitz DL. 1998. Integrating indigenous resource management with wildlife conservation: a case study of Batai Ai National Park, Sarawak Malaysia. Human Ecol 26: 371-403.

Iskandar J, Iskandar BS, Partasasmita R. 2016. The local knowledge of the rural people on species, role, and hunting of bird: case study in Karangwangi Village, West Java, Indonesia. Biodiversitas 17 (2): 435-446.

Iskandar J, Iskandar BS. 2011. Agroecosystem of Sundanese People. Kiblat, Bandung.

Iskandar J. 2014. Human \& environment with various changes. Graha Ilmu, Yogyakarta.

Iskandar J. 2015. Animal diversity: ecological benefits for human being Graha Ilmu, Yogyakarta [Indonesian].

Iskandar J. 2017. Ecology and sustainable development. Edition revision. Program of Environmental Study (PSMIL), Padjadjaran University Bandung [Indonesian].

Iskandar J. 2018. Ethnobiology, ethnoecology and sustainable development. Plantaxia, Yogyakarta [Indonesian]

IUCN Red List. http: //www.iucnredlist.org/about.

Maffi L. 1999. Linguistic diversity. In Posey D. (ed) Cultural and spiritual values of biodiversity. Intermediate Technology Publication., London.

Newing H, Eagle CM, Puri RK, Watson CW, 2011. Conducting research in conservation: social science methods and practice. Routledge Taylor \& Francis Group, London and New York.

Nijman V, Nekaris KA. 2014. Traditions, taboos and trade in slow lorises in Sundanese communities in Southern Java, Indonesia. Endangered Species Res 25: 79-88. DOI: 10.3354/esr00610.

Nikijuluw VPH. 1998. Identification of indigenous coastal fisheries management (ICFM) system in Sulawesi, Maluku, and Irian Jaya. J Coast Sea. 1 (2): 40-56 [Indonesian].

Partasasmita R, Iskandar J, Malone N. 2016a. Karangwangi people's (South Cianjur, West Java, Indonesia) local knowledge and wildlife conservation. Biodiversitas 17 (1): 154-161 DOI: 10.13057/biodiv/d170123.
Partasasmita R, Shanida SS, Iskandar J, Megantara EN, Husodo T, Malone N. 2016b. Human-Leopard Conflict in Girimukti Village, Sukabumi, Indonesia. Biodiversitas 17: 783-790

Pawarti A, Purnaweni H, Anggoro DD. 2012. Value of conservation in local wisdom of Lubuk Larangan of Ngalau Agung in Surau Hamlet, Dhramaraya District, West Sumatera Province. National Seminar Proceeding of Management of Natural Resources and Environment. Semarang 11 September 2012 [Indonesian].

Permana S, Iskandar J, Parikesit. 2018. Local knowledge on rice variations (landraces) of the Naga community, West Java, Indonesia. Asian J Ethnobio 1 (1): 1-8.

Permana S. 2015. Kampung Naga: traditional ecological and conservation of plant biodiversity. Plantaxia, Bogor.

PLN-LPPM Unpad. 2017. Biodiversity management plan upper Cisokan pumped storage [Research Report]. University of Padjadjaran, Bandung.

Puri RK. 2005. Deadly dances in the Bornean rainforest: hunting knowledge of the Benaljui. KITLV Press, Nederlands.

Raharyono D, Paripurno ET. 2001. Tiger friend with nature. The Gibbon Foundation, Jakarta.

Rao RR. 2002. Tribal Wisdom and Conservation of Biological Diversity. In Stepp JR, Wyndham FS, and Zarger (eds), Ethnobiology and Biocultural. The International Society of Ethnobiology, pp.84-94.

Rye S. 2000. Wild pig, 'pig men', and transmigrant in the rain forest of Sumatra. In Knight J. (ed), natural enemies: people-wildlife conflicts in anthropological perspective. Routledge, London.

Shanida SS, Partasasmita P, Hudoso T. Parikesit, Febriato P, Meganatara EN. 2018. The existence of Javan Leopard (Panthera pardus melas Cuvier, 1809) in the non-conservation forest areas of Cisokan, Cianjur, West Java, Indonesia. Biodiversitas 19: 42-46.

Toledo VM. 1992. Indigenous people and biodiversity. Institute of Ecology National University of Mexico.

Werner O, Bernard HR. 1994. Ethnographic sampling. Cult Anthropol Meth J 6 (2): 7-9.

Wessing R. 1978. Cosmology and social behavior in West Java settlement. Center for International Studies, Southeast Asia Series No.47, Ohio University.

Wessing R. 1993. A Change in the forest: myth and history in West Java. J Southeast Asian Studies 24 (1): 1-17.

Wessing R. 1995. The last tiger in East Java: symbolic continuity in ecological change. Asian Folklore Studies 54: 191-218.

Whitten T, Soeriatmadja RE, Afiff SA. 1999. Ecology of Java and Bali. Periplus, Singapore [Indonesian]. 